\title{
Pengaruh, Brand Image Dan Store Atmosphere Terhadap Keputusan Pembelian Pada Konsumen Badan Usaha Milik Desa (BUMDES) Mart Banjaran
}

\author{
Eli Achmad Mahiri \\ Dosen Tetap Fakultas Ekonomika dan Bisnis Universitas Majalengka \\ eliachmadmahiri@gmail.com
}

\begin{abstract}
ABSTRAK
Penelitian ini dilakukan di BUMDES Mart Banjaran Majalengka dan bertujuan untuk mengetahui bagaimana pengaruh Brand Image dan Store Atmosphere terhadap Keputusan Pembelian pada konsumen BUMDes Mart Banjaran dalam rangka meningkatkan daya saing perusahaan desa di era globalisasi Populasi pada penelitian ini adalah infinite population dan teknik pengambilan sampel yang digunakan dalam penelitian ini adalah non probability sampling dengan metode pendekatan Insidental sampling. Metode penelitian yang digunakan menggunakan metode survey dengan pendekatan deskriptif dan verifikatif, uji instrumen yang digunakan dalam penelitian ini adalah uji validitas dan uji reliabilitas. Analisis data yang digunakan dalam penelitian ini adalah analisis regresi berganda, koefisien determinasi, dan uji hipotesis. Hasil penelitian menunjukkan bahwa brand image berpengaruh positif dan signifikan terhadap keputusan pembelian, dan store atmosphere berpengaruh positif dan signifikan terhadap keputusan pembelian.
\end{abstract}

Kata Kunci : Brand Image, Store Atmosphere, dan Keputusan Pembelian.

\begin{abstract}
This research was conducted at BUMDES Mart Banjaran Majalengka and aims to determine how the influence of Brand Image and Store Atmosphere on Purchasing Decisions of BUMDes Mart Banjaran consumers in order to increase the competitiveness of rural companies in the era of globalization. The population in this study is the infinite population and the sampling technique used. in this study is a non probability sampling with incidental sampling approach method. The research method used is a survey method with descriptive and verification approaches, the test instruments used in this study are validity and reliability tests. The data analysis used in this research is multiple regression analysis, the coefficient of determination, and hypothesis testing. The results showed that brand image has a positive and significant effect on purchasing decisions, and store atmosphere has a positive and significant effect on purchasing decisions.
\end{abstract}

Keywords: Brand Image, Store Atmosphere, and Purchase Decisions.

\section{PENDAHULUAN}

\section{Latar Belakang}

Ekonomi memiliki bagian yang tidak bisa dipisahkan dari kehidupan manusia. Ekonomi juga memiliki peran penting untuk menjaga kestabilan kehidupan berbangsa dan bernegara. Tingkat pertumbuhan dan pembangunan suatu Negara dapat dilihat dari indikator ekonominya. Begitupun dengan perusahaan/organisasi, peran ekonomi dalam perusahaan tentu sangat penting untuk mendorong keberhasilan perusahaan/organisasi. Di era ekonomi global yang semakin maju saat ini akan mendorong manajer perusahaan meningkatkan produktivitas dalam bidang produksi, pemasaran dan strategi
perusahaan.Kegiatan tersebut dilakukan sebagai usaha perusahaan dalam memaksimalkan keuntungan ditengah persaingan ekonomi global yang semakin ketat.

Keadaan ekonomi dalam era globalisasi dewasa ini membuat persaingan bisnis menjadi semakin tajam, baik pasar domestik maupun pasar global. Daya beli konsumen semakin terbatas, konsumen semakin kritis dalam melakukan pembelian dan konsumen memiliki banyak alternatif untuk memenuhi kebutuhannya. Perkembangan bidang industri, jasa dan dagang sangat berperan penting dalam perkembangan perekonomian disuatu negara, perekonomian mampu memberikan perubahan-perubahan yang berarti bagi kehidupan masyarakat. Perubahan kondisi 
perekonomian Indonesia mengakibatkan semakin meningkatanya bisnis ritel atau eceran. Hal ini ditandai dengan semakin banyaknya bisnis ritel modern yang bermunculan, fenomena ini tidak hanya terjadi di kota-kota besar di Indonesia dengan konsep one stop shoping, yang menyediakan semua kebutuhan berbelanja di suatu tempat perbelanjaan (Ma'ruf, 2005:24)

Ma'ruf (2005:24) mengemukakan, adanya globalisasi juga merupakan faktor utama terciptanya permintaan atau meningkatkan permintaan barang dan jasa ritel. Gaya hidup adalah salah satu aspek kehidupan masyarakat yang dipengaruhi oleh faktor ini. Oleh karena itu, banyak peritel besar mengamati perkembangan globalisasi, khususnya perkembangan yang berpengaruh pada kehidupan masyarakat.

Bisnis ritel merupakan aktivitas bisnis yang melibatkan penjualan barang dan jasa secara langsung kepada konsumen akhir. Pada perkembangannya, bisnis ritel di Indonesia sendiri mulai bertransformasi dari bisnis ritel tradisional menjadi bisnis ritel modern. Perkembangan bisnis ritel modern sendiri di Indonesia sudah semakin menjamur di seluruh wilayah Indonesia. Jika dilihat sekarang sudah semakin banyak supermarket atau minimarket di desa-desa atau perkampungan. Hal ini terjadi karena perilaku atau kebiasaan orang-orang yang dahulunya sering berbelanja di pasar tradisional namun sekarang lebih senang berbelanja di minimarket atau supermarket yang lebih praktis dan nyaman. Fenomena ini pun langsung dimanfaatkan oleh produsen lainnya untuk membuat toko-toko retail berbasis minimarket dan lainnya untuk menarik perhatian dan minat konsumen untuk mengubah kebiasaan berbelanja para konsumen.

Keputusan pembelian merupakan usaha konsumen untuk mengidentifikasikan semua pilihan yang mungkin untuk memecahkan persoalan itu dan menilai pilihan-pilihan secara sistematis dan objektif serta sasaran-sasarannya yang menentukan keuntungan serta kerugiannya masing-masing. Schiffman dan Kanuk (2008:485) mendefinisikan keputusan merupakan seleksi terhadap dua pilihan alternatif atau lebih, dengan perkataan lain, pilihan alternatif harus tersedia bagi seseorang ketika mengambil keputusan. Sebaliknya, jika konsumen tersebut tidak mempunyai alternatif untuk memilih dan benar-benar terpaksa melakukan pembelian tertentu dan tindakan tertentu, maka keadaan tersebut bukan merupakan suatu keputusan. Sedangkan Peter dan Olson (2005:162), mengemukakan keputusan pembelian adalah proses pengintegrasian yang mengkombinasikan pengetahuan untuk mengevaluasi dua atau lebih perilaku alternatif dan memilih salah satu diantaranya. Dari dua pengertian tersebut, ditarik kesimpulan bahwa keputusan merupakan suatu eksekusi atas seleksi ketika seseorang dihadapkan pada minimal dua pilihan dengan melibatkan aspek kognisi, perhatian, pemahaman, serta proses penerjemahaan informasi. Dalam beberapa situasi, konsumen mungkin mencari informasi tambahan dan dalam situasi lain mereka hanya meninjau kembali apa yang sudah mereka ketahui (Schiffman dan Kanuk, 2008:487). Rangsangan pemasaran untuk pembelian produk terdiri dari $4 \mathrm{P}$ untuk produk fisik dan 7P untuk produk jasa, yaitu: produk, harga, tempat, promosi, orang, proses dan bukti fisik. Rangsangan lain adalah kekuatan-kekuatan utama dalam lingkungan, yaitu: ekonomi, teknologi, politik dan budaya. Rangsangan-rangsangan ini mempengaruhi pembeli dan berubah menjadi tanggapan pembeli untuk memutuskan pilihan produk atau jasa, merek, toko, waktu dan jumlah yang juga akan dijadikan indikator dalam keputusan pembelian. Salah satu unsur dalam keputusan pembelian adalah kelengkapan produk yang disediakan oleh pelaku bisnis. Oleh karena itu pelaku usaha harus membuat keputusan yang tepat mengenai kelengkapan produk yang dijual, karena dengan kelengkapan produk di sebuah toko akan memudahkan konsumen dalam memilih dan membeli berbagai macam produk sesuai dengan keinginan mereka.

Menurut Kotler (2007:346) menyatakan bahwa Brand image adalah persepsi dan keyakinan yang dilakukan oleh konsumen, seperti tercermin dalam asosiasi yang terjadi dalam memori konsumen. Sedangkan menurut Freddy Rangkuty (2002:43) brand image adalah sekumpulan asosiasi merek yang terbentuk dibenak konsumen. Konsumen memandang brand image sebagai bagian yang terpenting dari suatu produk, karena brand image mencerminkan tentang suatu produk. Dengan kata lain, brand image merupakan salah satu unsur penting yang dapat mendorong konsumen untuk membeli produk. Semakin baik brand image yang melekat pada produk maka konsumen akan semakin tertarik untuk membeli produk tersebut. Menurut Sutisna (2001:83) ada beberapa manfaat dari brand image yang positif, yaitu : 1) Konsumen dengan image yang positif terhadap suatu brand, lebih memungkinkan untuk melakukan pembelian. 2) Perusahaan dapat mengembangkan lini produk dengan memanfaatkan image positif yang telah terbentuk terhadap brand produk lama. 3) Kebijakan family branding dan leverage branding dapat dilakukan jika brand image produk yang telah positif. Faktor lain yang mempengaruhi keputusan pembelian dalam penelitian ini adalah suasana toko atau lingkungan, 
baik fisik maupun non fisik yang dapat menarik konsumen untuk melakukan pembelian.

Store atmosphere merupakan kondisi fisik dari sebuah toko baik dilihat dari luar toko maupun dari dalam toko. Store atmosphere (Suasana toko) memberikan ransangan tersendiri untuk menarik perhatian konsumen ketika berbelanja disebuah toko. Toko ritel modern pada jaman sekarang berlombalomba menciptakan suasana toko yang menarik, yang disesuaikan dengan konsep yang diusung oleh toko tersebut. Kotler (2002:164) mendefinisikan store atmosphere adalah lingkungan pembelian yang dirancang dengan baik untuk mempengaruhi emosional konsumen yang dapat meningkatkan pembeliannya. Sedangkan menurut Gilbert dalam Foster (2008:61) menyatakan bahwa store atmosphere merupakan kombinasi dari pesan secara fisik yang telah direncanakan, store atmosphere dapat digambarkan sebagai perubahaan terhadap perencanaan lingkungan pembelian yang menghasilkan efek emosional khusus yang dapat menyebabkan konsumen melakukan tindakan pembelian. Store atmosphere dapat disimpulkan merupakan suatu kegiatan yang dilakukan dalam mendesain ruangan toko sesuai dengan barang yang dijual dan memanfaatkan fasilitas yang ada, dan dengan menentukan tema yang sesuai yang mampu membuat suasana toko menjadi menarik perhatian konsumen. Store atmosphere merupakan pertimbangan tersendiri bagi konsumen karena ketika berbelanja juga membutuhkan suasana yang nyaman sehingga betah berbelanja ditoko tersebut. Store atmosphere menjadi pertimbangan konsumen ketika membeli di toko, karena suasana toko memiliki berbagai indikator teoritis. Indikator teoritis dari store atmosphere antara lain, kondisi dalam toko (in store) terdiri dari pencahayaan, tata letak produk, kebersihan, fasilitas, pendingin ruangan, aroma, dan kondisi luar toko (out store) terdiri dari pintu masuk, area sekitar dan lahan parkir. Untuk dapat menciptakan atmosphere yang menyenangkan, maka perlu diciptakan store atmosphere yang baik. Menurut Shari Waters (Guide form www.about;retail): "The physical characteristics and surrounding influence of a retail store that is used to create an image in order to attract customers, Examples: We have used lighting and trendy fixtures to create a hip atmosphere for our young customers". Shari Waters menyatakan bahwa karakteristik fisik dan pengaruh yang mengelilingi suatu bisnis ritel lah yang dapat menimbulkan citra dalam usaha untuk menarik konsumen, contohnya kita harus menciptakan pencahayaan dan penataan yang menarik untuk menciptakan suasana yang pas untuk pengunjung toko kita. Store atmosphere tidak hanya dapat memberikan suasana lingkungan pembelian yang menyenangkan saja, tetapi juga dapat memberikan nilai tambah terhadap produk yang dijual. Selain itu, store atmosphere juga akan menentukan citra toko itu sendiri. Citra toko yang baik dapat menjamin kelangsungan hidup perusahaan untuk bertahan terhadap persaingan dalam membentuk pelanggan yang loyal. Store atmosphere sebagai salah satu sarana komunikasi yang dapat berakibat positif dan menguntungkan dibuat semenarik mungkin. Tetapi sebaiknya mungkin juga dapat menghambat proses pembelian. Suatu proses pemasaran yang dilakukannya adalah retail dan bertujuan untuk menciptakan kenyamanan bagi konsumen. Minimal konsumen akan merasa betah saat berada di toko tersebut dan hal ini akan membuat konsumen untuk memutuskan pembelian di toko tersebut.

BUMDes dalam pasal 1 ayat (6) Peraturan Menteri Dalam Negeri Nomor 39 Tahun 2010 Tentang Badan Usaha Milik Desa, yang menyatakan bahwa BUMDes adalah usaha desa yang dibentuk/didirikan oleh pemerintah desa yang kepemilikan modal dan pengelolaannya dilakukan oleh pemerintah desa dan masyarakat. Sedangkan menurut pusat kajian dinamika sistem pembangunan (2007) Badan Usaha Milik Desa (BUMDes) adalah lembaga usaha desa yang dikelola oleh masyarakat dan pemerintah desa dalam upaya memperkuat perekonomian desa dan di bentuk berdasarkan kebutuhan dan potensi desa..

Kondisi persaingan pasar yang semakin ketat mendorong BUMDes Mart untuk terus menerus memperkuat citra mereknya agar dapat meraih posisi tertinggi dihati konsumen. Berbagai macam strategi pemasaran telah dilakukan oleh BUMDes Mart guna memperkuat citra mereknya dibenak konsumen, seperti terus menerus menciptakan strategi-strategi dan ide-ide yang inovatif dan menjaga kualitas produk yang dijualnya. Berbagai macam strategi yang telah dilakukan oleh BUMDes Mart diharapkan mampu memperkuat citra positif BUMDes Mart dan pada akhirnya diharapkan citra merek ini dapat mempengaruhi konsumen dalam memutuskan keputusan pembelian.

BUMDes Mart ini memiliki reputasi yang cukup baik dimata konsumen atau masyarakat sekitar karena BUMDes Mart selalu memberikan pelayanan yang baik terhadap konsumen, jika di alfamart kita melayani sendiri untuk mengambil produk yang dinginkan berbeda dengan di BUMDes Mart ini kita dilayani oleh penjual, harga yang ditawarkan pun lebih murah jika dibandingkan dengan alfamart dan produk yang dijual di BUMDes Mart ini sama 
berkualitasnya dengan produk yang dijual di alfamart.

Berdasarkan uraian latar belakang di atas, maka penulis bermaksud untuk melakukan penelitian dengan judul "Pengaruh Brand Image dan Store Atmosphere Terhadap Keputusan Pembelian Pada Konsumen BUMDES Mart Banjaran Majalengka Dalam Rangka Meningkatkan Daya Saing Perusahaan Desa Di Era Globalisasi”.

\section{Rumusan Masalah}

Berdasarkan latar belakang yang telah diuraikan di atas, maka masalah dalam penelitian ini dapat dirumuskan sebagai berikut :

1. Bagaimana pengaruh Brand image terhadap keputusan pembelian di BUMDes Mart Banjaran Majalengka

2. Bagaimana pengaruh Store Atmosphere terhadap keputusan pembelian di BUMDes Mart Banjaran Majalengka

\section{Tujuan Penelitian}

Adapun tujuan penulis melakukan penelitian ini adalah sebagai berikut :

1. Untuk mengetahui pengaruh brand image terhadap keputusan pembelian di BUMDes Mart Banjaran Majalengka

2. Untuk mengetahui pengaruh store atmosphere terhadap keputusan pembelian di BUMDes Mart Banjaran Majalengka

\section{KAJIAN PUSTAKA}

\section{Brand Image}

Menurut Aaker dan Biel (1993) Brand Image (Citra Merek) adalah penilaian konsumen terhadap merek tersebut dalam sebuah pasar. Penciptaan tersebut dapat tercipta berdasarkan pengalaman pribadi maupun mendengar reputasinya dari orang lain atau media. Brand image adalah persepsi dan keyakinan yang dilakukan oleh konsumen, seperti tercermin dalam asosiasi yang terjadi dalam memori konsumen (Kotler 2007:346).

Sedangkan menurut Freddy Rangkuti (2002:43) Brand image adalah sekumpulan asosiasi merek yang terbentuk di benak konsumen. Konsumen yang terbiasa menggunakan brand tertentu cenderung memiliki konsistensi terhadap brand image. Brand image berkaitan antara asosiasi dengan brand karena ketika kesan-kesan brand yang muncul dalam ingatan konsumen meningkat disebabkan semakin banyaknya pengalaman konsumen dalam mengkonsumsi atau membeli brand tersebut. Konsumen lebih sering membeli produk dengan merek yang terkenal karena merasa lebih nyaman dengan hal-hal yang sudah dikenal, adanya asumsi bahwa merek terkenal lebih dapat diandalkan, selalu tersedia dan mudah dicari, dan memiliki kualitas yang tidak diragukan, sehingga merek yang lebih dikenal lebih sering dipilih konsumen dari pada merek yang tidak terkenal (Aaker,1991).

Dari beberapa teori para ahli di atas maka dapat disimpulkan bahwa brand image adalah keyakinan pada suatu nama, symbol/desaign dan kesan yang dimilki konsumen terhadap suatu brand yang terbentuk di benak konsumen.

\section{Fungsi dan Manfaat Brand Image}

Boush dan Jones (dalam Kahle \& Kim, 2006: 6-8) mengemukakan bahwa brand image (citra merek) memiliki beberapa fungsi, diantaranya:

\section{Pintu masuk pasar (Market Entry)}

Berkaitan dengan fungsi market entry, citra merek berperan penting dalam hal pioneering advantage, brand extension, dan brand alliance. Produk pionir dalam sebuah kategori yang memiliki citra merek kuat akan mendapatkan keuntungan karena biasanya produk follower kalah pamor dengan produk pionir, misalnya Aqua. Bagi follower tentunya akan membutuhkan biaya tinggi untuk menggeser produk pionir yang memilki citra merek kuat tersebut. Disinilah keuntungan produk pionir (first-mover/pioneering advantages) yang memilki citra merek kuat dibandingkan produk pionir yang memilki citra merek kuat dibandingkan produk pionir yang memilki citra lemah atau produk komonditi tanpa merek.

2. Sumber nilai tambah produk (Source of Added Product Value)

Fungsi berikutnya dari citra merek adalah sebagai sumber nilai tambah produk (source of added product value). Para pemasar mengakui bahwa citra merek tidak hanya merangkum pengalaman konsumen dengan produk dari merek tersebut, tapi benar-benar dapat mengubah pengalaman itu. Sebagai contoh, konsumen terbukti merasa bahwa makanan atau minuman dari merek favorit mereka memilki rasa yang lebih dari kompetitor jika diuji secara unblinded dibandingkan jika diuji secara blinded taste tests (Allison \& Uhl, 1964). Dengan demikian citra merek memilki peran yang jauh lebih kuat dalam menambah nilai produk dengan mengubah pengalaman produk (Aaker \& Stayman, 1992: Puto \& Wells, 1984).

3. Penyimpanan nilai perusahaan (Coporate Store of Value) 
Nama merek merupakan penyampaian nilai dari hasil investasi biaya iklan dan pengkaitan kualitas produk yang terakumulasikan. Perusahaan dapat menggunakan penyimpan nilai ini untuk mengkonversi ide pemasaran strategis menjadi keuntungan kompetitip jangka panjang. Misalnya, merek Hallmark diuntungkan dari keputusan yang dibuat selama 1950 untuk mensponsori beberapa program televisi berkualitas tinggi secara khusus setiap tahun.

4. Kekuatan dalam penyaluran produk (Channel Power)

Sementara itu, nama merek dengan citra yang kuat berfungsi baik sebagai indikator maupun kekuatan dalam saluran distribusi (channel power). Ini berarti merek tidak hanya berperan penting hirizontal dalam menghadapi pesaing mereka, tetapi juga secara vertikal dalam memperoleh saluran distribusi dan memilki kontrol, dan daya tawar terhadap persyaratan yang dibuat distributor (Aaker, 1991: Porter, 1974). Sebgai contoh, strategi merek eksistensi coca cola bisa dibilang menyelesaikan tiga fungsi sekaligus. Perpanjangan izin masuk pasar dengan biaya lebih rendah, menghambat persaingan dengan menguasai shelf space, dan juga dapat memberikan daya tawar dalam hal negosiasasi perdagangan, karena Coca Cola dianggap memiliki kekuatan dalam meningkatkan penjualan.

Manfaat merek bagi produsen menurut Keller dalam Tjiptono (2005:20-21), dikatakan bahwa merek berperan sebagai:

1. Sarana identifikassi untuk memudahkan proses penanganan atau pelacakan produk bagi perusahaan, terutama dalam pengorganisasian persediaan dan pencatatan akuntansi.

2. Bentuk proteksi hukum terhdap fitur yang unik. Merek bisa mendapatkan perlindungan property intelektual. Namun merek bisa diproteksi melalui merek dagang terdaftar (registered trademarks), proses pemanukfaturan bisa dilindungi melalui hak cipta (copyrights) dan desain. Hak-hak property intelektual ini memberikan jaminan bahwa perusahaan dapat berinvestasi dengan aman dalam merek yang dikembangkannya dan meraup manfaat dari aset bernilai tersebut.

3. Signal tingkat kualitas bagi para pelanggan yang puas, sehingga mereka bisa dengan mudah memilih dan membelinya lagi dilain waktu. Loyalitas merek seperti ini menghasilkan predictability dan security permintaan bagi perusahaan dan menciptakan hambatan masuk yang menyulitkan bagi perusahaan lain untuk masuk pasar.

4. Sarana menciptakan asosiasi dan makna unik yang membedakan produk dari para pesaing.

5. Sumber keunggulan kompetitif, terutama melalui perlindungan hukum, loyalitas pelanggan, dan citra unik yang terbentuk di dalam benak konsumen.

6. Sumber financial returns, terutama menyangkut pendapatan masa datang.

\section{Faktor-faktor yang Membentuk Brand Image}

Menurut Shiffman dan Kanuk (2006:135) menyebutkan faktor-faktor pembentuk brand image adalah sebagai berikut:

1. Kualitas atau mutu, berkaitan dengan kualitas produk yang ditawarkan oleh produsen dengan merek tertentu.

2. Dapat dipercaya atau diandalkan, berkaitan dengan pendapat dan kesepakatan yang dibentuk oleh masyarakat tentang suatu produk yang dikonsumsi.

3. Kegunaan atau manfaat, yang terkait dengan fungsi dari suatu produk yang bisa dimanfaatkan oleh konsumen.

4. Pelayanan, yang berkaitan dengan tugas produsen dalam melayani konsumennya.

5. Resiko berkaitan dengan untung rugi yang dialami oleh konsumen.

6. Harga, dalam hal ini berkaitan dengan tinggi rendahnya atau banyak sedikitnya jumlah uang yang dikeluarkan konsumen untuk mempengaruhi suatu produk, juga dapat mempengaruhi citra jangka panjang.

7. Citra yang dimilki merek itu sendiri, yaitu berupa pelanggan, kesempatan dan informasi yang berkaitan dengan suatu merek dari produk tertentu.

\section{Store Atmosphere}

Store Atmosphere merupakan salah satu elemen penting dari retailing mix yang mampu mempengaruhi proses keputusan pembelian konsumen, karena dalam proses pembeliannya konsumen tidak hanya memberi respon terhadap barang dan jasa yang ditawarkan oleh pengecer, tetapi juga memberikan respon terhadap lingkungan pembelian yang di ciptakan oleh pengecer. Menurut Berman dan Evans (2010:103) "Strore Atmosphere merupakan kombinasi dari karakteristik fisik toko seperti arsitektur, tata letak, pencahayaan, 
pemajangan, warna, temperature, music, aroma yang secara menyeluruh akan menciptakan citra dalam benak konsumen". Menciptakan dan memelihara citra sangat tergantung pada suasana perusaahaan atau toko. Suasana mengacu pada karakteristik fisik toko yang digunakan untuk mengembangkan citra dan menarik pelanggan. Suasana mengacu pada desain lingkungan melalui komunikasi visual, pencahayaan, warna, musik, dan aroma untuk merangsang pandangan pelanggan dan tanggapan emosional dan akhirnya mempengaruhi perilaku pembelian (Levy dan Weitz, 2001:576).

Sedangkan menurut Kotler (2008:61) store atmosphere adalah suasana (atmosphere) setiap toko mempunyai tata letak fisik yang memudahkan atau menyulitkan untuk berputar-putar di dalamnya, setiap toko mempunyai penampilan yang berbeda-beda baik itu tidak tertata baik, menarik, megah dan suram. Suatu toko harus membentuk suasana terencana yang sesuai dengan pasar sasarannya dan dapat menarik konsumen untuk membeli di toko tersebut. Gilbert (2003:129) menjelaskan bahwa store atmosphere merupakan kombinasi dan peran secara fisik yang telah direncanakan. Store Atmosphere dapat digambarkan sebagai perubahan terhadap perencanaan lingkungan pembelian yang menghasilkan efek emosional khusus yang dapat menyebabkan konsumen melakukan tindakan pembelian.

Berdasarkan pengertian para ahli di atas maka dapat disimpulkan bahwa store amtmosphere adalah suatu kegiatan yang dilakukan dalam mendesain ruangan toko sesuai dengan barang yang dijual dan memanfaatkan fasilitas yang ada melalui komunikasi visual, pencahayaan, warna musik dan penciuman untuk merangsang persepsi dan emosi pelanggan hingga akhirnya mempengaruhi perilaku pembelanjaan mereka.

\section{Faktor-faktor Penciptaan Store Atmosphere}

Beberapa faktor yang berpengaruh dalam menciptakan suasana toko menurut Lamb, Hair dan Mc Daniel (2001:108), yaitu :

1. Jenis karyawan, Karakteristik umum karyawan, sebagai contoh : rapi, ramah, berwawasan luas, atau berorientasi pada pelayanan.

2. Jenis barang dagangan dan kepadatan, Jenis barang dagangan yang dijual bagaimana barang tersebut dipajang menetukan suasana yang ingin diciptakan oleh pengecer.

3. Jenis perlengkapan tetap (fixture) dan kepadatan, Perlengkapan tetap bisa elegan (terbuat dari kayu jati), trendi (dari logam dan kaca tidak tembus pandang). Perlengkapan tetap harus konsisten dengan suasana umum yang ingin diciptakan.

4. Bunyi suara, Bunyi suara bisa menyenangkan atau menjengkelkan bagi seorang pelanggan. Musik juga bisa membuat konsumen tinggal lebih lama di toko. Musik dapat mengontrol lain lintas di toko, menciptakan suasana citra, dan menarik atau mengarahkan perhatian pembelinya.

5. Aroma, Bau bisa merangsang maupun mengganggu penjualan. Penelitian menyatakan bahwa orang-orang menilai barang dagangan secara lebih positif, menghabiskan waktu yang lebih untuk berbelanja dan umumnya bersuasana hati lebih baik bila ada aroma yang dapat disetujui. Para pengecer menggunakan wangi antara lain sebagai perluasan dan strategi eceran.

6. Faktor visual, Warna dapat menciptakan suasana hati atau memfokuskan perhatian, warna merah kuning atau orange dianggap sebagai warna yang hangat dan kedekatan yang diinginkan. Warnawarna yang menyejukkan seperti hijau, dan violet digunakan untuk membuka tempat yang tertutup, dan menciptakan suasana yang elegan dan bersih. Pencahayaan juga dapat mempunyai pengaruh penting pada suasana toko. Konsumen taktut untuk berbelanja pada malam hari di daerah tertentu dan lebih merasa senang bila tempat itu memiliki pencahayaan yang kuat untuk alasan keselamatan. Tampak luar suatu toko juga mempunyai pengaruh pada suasana yang diinginkan dan hendaknya tidak menerbitkan kesan pertama yang mengkhawatirkan bagi pembelanja.

\section{Cakupan Store Atmosphere}

Menurut Levi dan Weitz (2001:118), Store atmosphere terdiri dari dua hal, yaitu Instore atmosphere dan Outstore atmosphere:

\section{Instore Atmosphere}

Instore Atmosphere adalah pengaturanpengaturan di dalam ruangan yang menyangkut:

a. Internal Layout merupakan pengaturan dari berbagai fasilitas dalam ruangan yang terdiri dari tata letak meja kursi pengunjung, tata letak meja kasir, dan tata letak lampu, pendingin ruangan, sound.

b. Suara merupakan keseluruhan alunan suara yang dihadirkan dalam ruangan untuk menciptakan kesan rileks yang terdiri dari live music yang disajikan restoran dan alunan suara musik dari sound system. 
c. Bau merupakan aroma-aroma yang dihadirkan dalam ruangan untuk menciptakan selera makan yang timbul dari aroma makanan dan minuman dan aroma yang ditimbulkan oleh pewangi ruangan.

d. Tekstur merupakan tampilan fisik dari bahanbahan yang digunakan untuk meja dan kursi dalam ruangan dan dinding ruangan.

e. Desain interior bangunan adalah penataan ruang-ruang dalam restoran kesesuaian meliputi kesesuaian luas ruangan pengunjung dengan ruas jalan yang memberikan kenyamanan, desain bar counter, penataan meja, penataan lukisan-lukisan, dan sistem pencahayaan dalam ruangan.

\section{Outstore atmosphere}

Outstore atmosphere adalah pengaturanpengaturan diluar ruangan yang menyangkut :

a. External Layout yaitu pengaturan tata letak berbagai fasilitas restoran diluar ruangan yang meliputi tata letak parkir pengunjung, tata letak papan nama, dan lokasi strategis.

b. Tekstur merupakan tampilan fisik dari bahanbahan yang digunakan bangunan maupun fasilitas diluar ruangan yang meliputi tekstur dinding bangunan luar ruangan dan tekstur papan nama luar ruangan.

c. Desain eksterior bangunan merupakan penataan ruangan-ruangan luar restoran meliputi desain papan nama luar ruangan, penempatan pintu masuk, bentuk bangunan dilihat dari luar, dan sistem pencahayaan luar ruangan.

\section{Keputusan Pembelian}

Menurut Kotler dan Keller (2012:227) Keputusan Pembelian adalah sebuah proses dimana konsumen mengenal masalahnya, mencari informasi mengenai produk atau merek tertentu dan mengevaluasi seberapa baik masing-masing alternatif tersebut dapat memecahkan masalahnya, yang kemudian mengarah kepada keputusan pembelian. Keputusan pembelian adalah proses pengintegrasian yang mengkombinasikan pengetahuan untuk mengevaluasi dua atau lebih perilaku alternatif dan memilih salah satu diantaranya (Peter dan Olson 2005:162).

Sedangkan Menurut Schiffman dan Kanuk (2008:485) mendefinisikan keputusan merupakan seleksi terhadap dua pilihan alternatif atau lebih, dengan perkataan lain, pilihan alternatif harus tersedia bagi seseorang ketika mengambil keputusan. Sebaliknya, jika konsumen tersebut tidak mempunyai alternatif untuk memilih dan benar-benar terpaksa melakukan pembelian tertentu dan tindakan tertentu, maka keadaan tersebut bukan merupakan suatu keputusan.

Konsumen umumnya melakukan tiga jenis keputusan pembelian yaitu pembelian yang direncanakan (fully planned purchase), pembelian yang terencana dengan berbagai pertimbangan (partially planned purchase), pembelian yang tidak direncanakan (unplanned purchase), suatu pembelian yang direncanakan adalah keputusan yang dilakukan konsumen dalam menjatuhkan pilihannya kepada suatu produk akibat dari perencanaan yang matang. Pembelian yang terencana dengan berbagai pertimbangan, bermaksud untuk menjatuhkan pilihan kepada produk yang sudah ada namun pemilihan merek ditunda saat pembelanjaan. Pembelian yang tidak direncanakan adalah pemilihan terhadap jenis produk yang sebelumnya tidak direncanakan untuk dipilih sebelumnya setelah dipicu oleh rangsangan oleh usahan para pemasar (Samuel,2007).

Pengambilan keputusan oleh konsumen untuk melakukan pembelian suatu prodak diawali kesadaran atas pemenuhan kebutuhan dan keinginan. Selanjutnya jika sudah disadari adanya keutuhan dan keinginan, maka konsumen akan mencari informasi mengenai keberadaan produk yang diinginkan. Dari berbagai informasi yang diperoleh konsumen akan melakukan seleksi atas alternatif-alternatif yang tersedia. Proses seleksi inilah yang disebut sebagai tahap evaluasi informasi.

\section{Faktor-faktor yang Mempengaruhi Keputusan} Pembelian

Proses keputusan pembelian konsumen dalam membeli atau mengkonsumsi produk atau jasa akan dipengaruhi oleh kegiatan pemasar dan lembaga lainnya serta penilaian dan persepsi konsumen itu sendiri. Proses keputusan pembelian terdiri dari pengenalan masalah, pencarian informasi, evaluasi alternatif, pembelian, dan kepuasan konsumen. pemahaman tentang faktor-faktor yang mempengaruhi keputusan konsumen akan memberikan pengetahuan kepada pemasar bagaimana menyusun strategi dan komunikasi pemasaran yang lebih baik. Persepsi konsumen akan mempunyai kesuakaan dan kebiasaan yang berbeda-beda sesuai dengan kondisi konsumen terutama didukung oleh kemampuan seseorang untuk mendapatkan suatu barang atau jasa.

Setiadi (2003:11-15), keputusan pembelian yang akan dilakukan oleh konsumen sangat dipengaruhi oleh faktor kebudayaan, sosial, pribadi dan pisikologis. 
1. Faktor kebudayaan merupakan faktor penentu yang mendasari keinginan dan perilaku seseorang. Faktor kebudayaan mempunyai pengaruh yang paling luas dan paling dalam terhadap perilaku konsumen. Pemasaran harus memahami peran yang dimainkan oleh budaya, sub-budayanya, dan kelas sosial pembeli.

2. Faktor sosial terdiri atas kelompok referensi, keluarga serta peran dan status seseorang dalam lingkungannya. Perilaku konsumen juga akan dipengaruhi oleh faktor-faktor sosial seperti kelompok kecil, keluarga, peran dan status sosial dari konsumen.

3. Faktor pribadi terdiri atas umur dan tahapan dalam siklus hidup, pekerjaan, keadaan ekonomi, gaya hidup, kepribadian dan konsep diri. Keputusan seorang pembeli juga dipengaruhi oleh karakteristik pribadi seperti umur dan tahap daur hidup pembeli, jabatan, keadaan ekonomi, gaya hidup, kepribadian dan konsep diri pembeli yang bersangkutan.

4. Faktor pisikologis terdiri atas motivasi, persepsi, proses belajar serta kepercayaan diri dari sikap. Pilihan pembelian seseorang juga dipengaruhi oleh faktor psikikologis yang utama, yaitu faktor motivasi, persepsi, proses belajar, serta kepercayaan dan sikap.

\section{Kerangka Pemikiran}

Keputusan pembelian merupakan usaha konsumen untuk mengidentifikasikan semua pilihan yang mungkin untuk memecahkan persoalan itu dan menilai pilihan-pilihan secara sistematis dan objektif serta sasaran-sasarannya yang menentukan keuntungan serta kerugiannya masing-masing. Dalam beberapa situasi, konsumen mungkin mencari informasi tambahan dan dalam situasi lain mereka hanya meninjau kembali apa yang sudah mereka ketahui.

Menurut Kotler dan Keller (2012:227) Keputusan Pembelian adalah sebuah proses dimana konsumen mengenal masalahnya, mencari informasi mengenai produk atau merek tertentu dan mengevaluasi seberapa baik masing-masing alternatif tersebut dapat memecahkan masalahnya, yang kemudian mengarah kepada keputusan pembelian.

Menurut Kotler (2010:184) dalam Nurmin dan Eramaya (2018:147), indikator keputusan pembelian terdiri dari 1) Pengenalan Masalah 2) Pencarian Informasi 3) Evaluasi Alternatif 4) Keputusan Pembelian. Dan 5) Perilaku Pasca Pembelian

Keputusan pembelian juga dapat dipengaruhi oleh Brand Image dan Store Atmosphere. Kelengkapan barang dagangan merupakan faktor yang sangat penting untuk menarik konsumen. Semakin lengkap sebuah toko maka semakin banyak menarik pengunjung yang datang untuk membeli produk mereka. Begitu pula dengan kelengkapan produk yang ditawarkan (variety) juga sangat mempengaruhi keputusan pembelian konsumen.

Menurut Aaker dan Biel (1993) Brand Image (Citra Merek) adalah penilaian konsumen terhadap merek tersebut dalam sebuah pasar. Penciptaan tersebut dapat tercipta berdasarkan pengalaman pribadi maupun mendengar reputasinya dari orang lain atau media.

Menurut Aaker dan Biel (2009:71) dalam Supriyadi dkk (2016:138) brand image memilki tiga indikator yaitu:

1. Citra perusahaan (corporate image)

2. Citra Produk (Product Image)

3. Citra Pemakai (Use Image)

Store Atmosphere merupakan salah satu elemen penting dari retailing mix yang mampu mempengaruhi proses keputusan pembelian konsumen selain kelengkapan produk dan brand image, karena dalam proses pembeliannya konsumen tidak hanya memberi respon terhadap barang dan jasa yang ditawarkan oleh pengecer, tetapi juga memberikan respon terhadap lingkungan pembelian yang di ciptakan oleh pengecer karena ketika berbelanja juga membutuhkan suasana yang nyaman sehingga betah berbelanja di toko tersebut dan hal ini akan membuat konsumen untuk memutuskan pembelian di toko tersebut.

Menurut Berman dan Evan (2010:103) "Strore Atmosphere merupakan kombinasi dari karakteristik fisik toko seperti arsitektur, tata letak, pencahayaan, pemajangan, warna, temperature, music, aroma yang secara menyeluruh akan menciptakan citra dalam benak konsumen".

Menurut Berman dan Evan (2001:601) dalam Putra Budi dan Lidya (2017:847), membagi elemen-elemen store atmosphere ke dalam 4 elemen, yaitu :

1. Exterior (bagian depan toko)

2. General interior (bagian dalam toko)

3. Store layout (tata tetak)

4. Interior display (dekorasi dalam toko)

Berdasarkan uraian kerangka pemikiran di atas, maka dapat dibuat paradigmanya seperti yang terlihat pada gambar. 


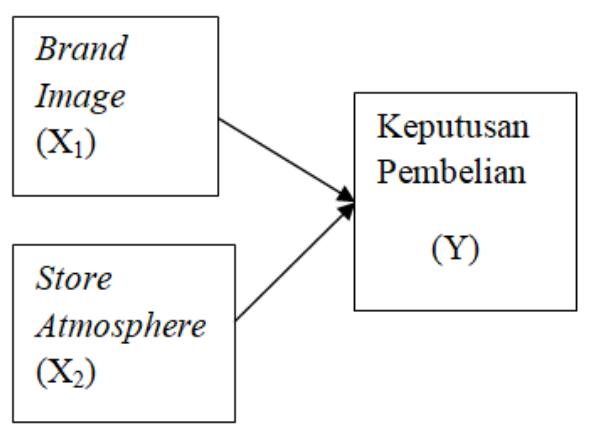

\section{Gambar Paradigma Pemikiran}

\section{Hipotesis}

Berdasarkan kerangka pemikiran di atas maka hipotesis yang penulis ajukan yaitu:.

H1: Adanya pengaruh brand image terhadap keputusan pembelian konsumen BUMDes Mart Banjaran Majalengka.

H2:Adanya pengaruh store atmosphere terhadap keputusan pembelian konsumen BUMDes Mart Banjaran Majalengka.

\section{METODE PENELITIAN}

\section{Metode Yang Digunakan}

Metode yang digunakan dalam penelitian ini adalah metode survey dengan pendekatan analisis deskriptif dan analisis verifikatif. metode deskriptif adalah penelitian yang dilakukan untuk menggambarkan variabel mandiri, baik hanya pada satu variabel atau lebih (variabel yang berdiri sendiri) tanpa membuat perbandingan dan mencari variabel itu dengan variabel lain.Sedangkan metode verifikatif adalah penelitian yang dilakukan terhadap populasi atau sampel tertentu dengan tujuan untuk menguji hipotesis yang telah ditetapkan.

\section{Operasionalisasi Variabel}

Variabel yang digunakan dalam penelitian ini adalah variabel independen (bebas) dan variabel dependen (terikat). Variabel Independen (Bebas) Brand Image $\left(\mathrm{X}_{1}\right)$, dan Store Atmosphere $\left(\mathrm{X}_{2}\right)$. Sedangkan Variabel dependen (Terikat) dalam penelitian ini yaitu keputusan pembelian (Y).

\section{Populasi dan Sampel}

Populasi pada penelitian ini adalah konsumen yang membeli di BUMDes Mart Banjaran Majalengka, populasi penelitian ini adalah infinite population dan teknik pengambilan sampel yang digunakan dalam penelitian ini adalah non probability sampling dengan metode pendekatan Insidental sampling.

\section{Pengujian Instrumen Penelitian}

Kesungguhan responden dalam menjawab pertanyaan sangat diharapkan, oleh karena itu, agar alat ukur valid dan dapat dipercaya sehingga dapat menggambarkan objek penelitian yang sebenarnya perlu diadakan yaitu dengan 2 (dua) macam cara pengujian berupa test of validity (uji kesahihan) dan test of reliability (uji kehandalan)

\section{Rancangan Analisis Data dan Uji Hipotesis}

Analisis yang dilakukan untuk menganalisis data dengan cara mendeskripsikan atau menggambarkan data yang terkumpul sebagaimana adanya tanpa bermaksud membuat kesimpulan yang berlaku untuk umum atau generalisasi. Variabel pada penelitian ini adalah Brand Image dan Store Atmosphere (variabel independen atau bebas) dan Keputusan Pembelian (variabel dependen atau terikat). Analisis veripikatif dilakukan untuk mengetahui kebenaran suatu hipotesis dengan langkah-langkah : pengujian asumsi klasik, analisis regresi linier berganda, dan analisis koefisien determinasi.

\section{Analisis Regresi Linier Berganda}

Dari penjelasan di atas, maka dapat disimpulkan bahwa analisis regresi linier berganda akan dilakukan bila jumlah variabel independennya minimal dua. Analisis regresi linier berganda dilakukan untuk mengetahui seberapa besar pengaruh antar dua variabel atau lebih, juga menunjukkan arah hubungan antar variabel, apakah memiliki arah hubungan positif atau negatif. model regresi dalam penelitian ini dapat dirumuskan sebagai berikut :

$$
\mathrm{Y}=\alpha+\mathrm{b}_{1} \mathrm{X}_{1}+\mathrm{b}_{2} \mathrm{X}_{2}+\mathrm{e} \quad \rightarrow(1)
$$

Sumber: Sugiyono (2015:275)

Dimana :

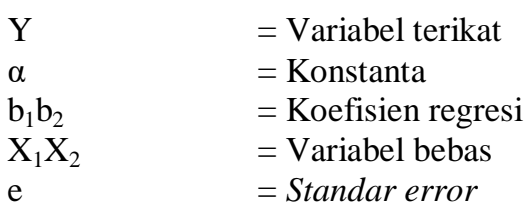

\section{Koefisien Determinasi}

Analisis koefisien determinasi digunakan untuk mengetahui seberapa besar pengaruh variabel independen terhadap variabel dependen, untuk mengukur seberapa besar pengaruh koefisien determinasi digunakan rumus sebagai berikut :

$$
\mathrm{KD}=\mathrm{r}^{2} \times 100 \%
$$

Keterangan :

$\begin{array}{ll}\mathrm{KD} & =\text { Nilai Koefisien Determinasi } \\ \mathrm{R}^{2} & =\text { Nilai Koefisien Kolerasi }\end{array}$ 


\section{Uji Hipotesis}

Untuk menguji hipotesis variabel bebas (independen) brand image $\left(\mathrm{X}_{1}\right)$ dan store atmosphere $\left(\mathrm{X}_{2}\right)$ terhadap variabel terikat (dependen) keputusan pembelian (Y, Untuk menghitung uji $\mathrm{F}$ dapat digunakan rumus sebagai berikut :

$$
\mathrm{F}_{\text {hitung }}=\frac{R^{2} / K}{\left(1-R^{2}\right) /(n-k-1)}
$$

Sumber : Sugiyono (2010:235)

Keterangan:

$\mathrm{R}^{2}=$ Koefisien kolerasi ganda

$\mathrm{k}=$ Jumlah variabel independen

$\mathrm{n}=$ Jumlah anggota sampel

Uji $F$ dilakukan dengan membandingkan $F_{\text {hitung }}$ dengan $F_{\text {tabel }}$ pada tingkat sifgnifikan $\alpha 5 \%$ dengan $\mathrm{dk}=\mathrm{n}-\mathrm{k}-1$. Berdasarkan rumusan masalah dan hipotesis atau dugaan sementara maka dilakukan uji hipotesis

\section{HASIL PENELITIAN DAN PEMBAHASAN}

\section{Hasil Penelitian}

\section{Uji Validitas}

Tabel 1. Hasil Uji Validitas Variabel Brand Image

\begin{tabular}{cccc}
\hline No.Item & $\mathbf{r}_{\text {hitung }}$ & $\begin{array}{c}\mathbf{r}_{\text {tabel }}(\boldsymbol{\alpha}= \\
\mathbf{5 \% )}\end{array}$ & Ket. \\
\hline 1 & 0,452 & 0,195 & Valid \\
2 & 0,476 & 0,195 & Valid \\
3 & 0,208 & 0,195 & Valid \\
4 & 0,636 & 0,195 & Valid \\
5 & 0,488 & 0,195 & Valid \\
6 & 0,484 & 0,195 & Valid \\
\hline
\end{tabular}

Sumber : Data diolah Tahun 2020

Berdasarkan hasil uji validitas dengan 6 pernyataan pada variabel Brand Image menunjukan bahwa $r_{\text {hitung }}$ $>r_{\text {tabel }}$ pada taraf signifikansi $(\alpha)=5 \%$ yakni sebesar 0,195 sehingga dapat disimpulkan bahwa seluruh item pernyataan tersebut valid.

Tabel 2. Hasil Uji Validitas Variabel Store Atmosphere

\begin{tabular}{cccc}
\hline No Item & $\mathbf{r}_{\text {hitung }}$ & $\begin{array}{c}\mathbf{r}_{\text {tabel }}(\boldsymbol{\alpha}= \\
\mathbf{5 \% )}\end{array}$ & Ket. \\
\hline 1 & 0,328 & 0,195 & Valid \\
2 & 0,236 & 0,195 & Valid \\
3 & 0,636 & 0,195 & Valid \\
4 & 0,658 & 0,195 & Valid \\
5 & 0,311 & 0,195 & Valid \\
6 & 0,579 & 0,195 & Valid \\
7 & 0,457 & 0,195 & Valid \\
8 & 0,297 & 0,195 & Valid \\
9 & 0,643 & 0,195 & Valid \\
\hline
\end{tabular}

Sumber : Data diolah Tahun 2020
Berdasarkan hasil uji validitas dengan 9 pernyataan pada variabel Store Atmosphere menunjukan bahwa $r_{\text {hitung }}>r_{\text {tabel }}$ pada taraf signifikansi $(\alpha)=5 \%$ yakni sebesar 0,195 sehingga dapat disimpulkan bahwa seluruh item pernyataan tersebut valid.

Tabel 3, Hasil Uji Validitas Variabel Keputusan Pembelian

\begin{tabular}{cccc}
\hline No Item & $\mathbf{r}_{\text {hitung }}$ & $\begin{array}{c}\mathbf{r}_{\text {tabel }}(\boldsymbol{\alpha}= \\
\mathbf{5 \% )}\end{array}$ & Ket. \\
\hline 1 & 0,549 & 0,195 & Valid \\
2 & 0,489 & 0,195 & Valid \\
3 & 0,200 & 0,195 & Valid \\
4 & 0,646 & 0,195 & Valid \\
5 & 0,623 & 0,195 & Valid \\
6 & 0,586 & 0,195 & Valid \\
7 & 0,721 & 0,195 & Valid \\
8 & 0,564 & 0,195 & Valid \\
\hline
\end{tabular}

Sumber : Data diolah Tahun 2020

Berdasarkan hasil uji validitas dengan 8 pernyataan pada variabel Keputusan Pembelian menunjukan bahwa $r_{\text {hitung }}>r_{\text {tabel }}$ pada taraf signifikansi $(\alpha)=5 \%$ yakni sebesar 0,195 sehingga dapat disimpulkan bahwa seluruh item pernyataan tersebut valid.

Maka dapat ditarik kesimpulan bahwa seluruh item pernyataan untuk variabel Kelengkapan Produk, Brand Image, Store Atmosphere dan Keputusan Pembelian yang digunakan dalam penelitian ini dinyatakan valid.

\section{Uji Reliabilitas}

\section{Tabel 4. Hasil Uji Reliabilitas}

\begin{tabular}{ccccc}
\hline Variabel & $\begin{array}{c}\text { Total } \\
\text { Item }\end{array}$ & $\begin{array}{c}\text { Nilai } \\
\text { Cronbach's } \\
\text { Alpha }\end{array}$ & $\begin{array}{c}\text { Nilai } \\
\text { krts }\end{array}$ & Ket. \\
\hline $\begin{array}{c}\text { Brand Image } \\
\text { Store }\end{array}$ & 6 & 0,718 & 0,60 & Reliabel \\
$\begin{array}{c}\text { Atmosphere } \\
\text { Keputusan }\end{array}$ & 9 & 0,774 & 0,60 & Reliabel \\
Pembelian & 8 & 0,819 & 0,60 & Reliabel \\
\hline
\end{tabular}

Sumber : Data diolah Tahun 2020

Hasil uji reliabilitas pada masing-masing variabel menunjukkan nilai Cronbach's Alpha yang lebih besar dibandingkan dengan nilai kritis, yakni, 0,718, 0,774 dan 0,819 lebih besar dari 0,60. Ini berarti bahwa seluruh pernyataan dalam kuisoner dinyatakan reliable.

\section{Analisis Regresi Linier Berganda}

Analisis regresi berganda pada umunya untuk menguji dua atau lebih variabel independen (Brand Image dan Store Atmosphere) terhadap variabel dependen (Keputusan Pembelian).. Hasil analisis regresi berganda dapat dilihat pada tabel berikut ini : 
Tabel 5. Hasil Analisis Regresi Linier Berganda

\begin{tabular}{|c|c|c|c|c|c|c|}
\hline \multicolumn{7}{|c|}{ Coefficients $^{\mathrm{a}}$} \\
\hline & & \multicolumn{2}{|c|}{$\begin{array}{l}\text { Unstandardized } \\
\text { Coefficients }\end{array}$} & \multirow{2}{*}{$\begin{array}{c}\text { Standardized } \\
\text { Coefficients } \\
\text { Beta }\end{array}$} & \multirow[b]{2}{*}{$\mathrm{t}$} & \\
\hline \multicolumn{2}{|c|}{ Model } & B & Std. Error & & & Sig. \\
\hline \multirow[t]{4}{*}{1} & (Constant) & 2.69 & 1.874 & & 1.438 & .15 \\
\hline & $\begin{array}{l}\text { Brand } \\
\text { Image }\end{array}$ & .35 & .097 & .268 & 3.688 & .00 \\
\hline & $\begin{array}{l}\text { Store } \\
\text { Atmosphere }\end{array}$ & .30 & .077 & .313 & 3.997 & .00 \\
\hline & $\begin{array}{ll}\text { a. Depen } \\
\text { Keputu }\end{array}$ & $\begin{array}{l}\text { ent } \mathrm{V} \\
\text { an } \mathrm{Pe}\end{array}$ & $\begin{array}{l}\text { riable: } \\
\text { nbelian }\end{array}$ & & & \\
\hline
\end{tabular}

Sumber : Output SPSS Versi 16, 2020

Berdasarkan tabel di atas, maka didapat persamaan model regresi linier berganda sebagai berikut :

$$
\begin{gathered}
\mathrm{Y}=2,695+0,359 \mathrm{X}_{1}+0,308 \mathrm{X}_{2} \\
\mathrm{Y}=\text { keputusan Pembelian } \\
\mathrm{X} 1=\text { Brand Image } \\
\mathrm{X} 2=\text { Store Atmosphere }
\end{gathered}
$$

\section{Analisis Koefisien Determinasi $\left(\mathbf{R}^{2}\right)$}

Analisis koefisien determinasi digunakan untuk mengetahui seberapa besar presentase pengaruh kelengkapan produk, brand image dan store atmosphere terhadap keputusan pembelian.: Berdasarkan perhitungan yang telah dilakukan maka dapat diketahui bahwa kontribusi brand image mempengaruhi keputusan pembelian yaitu sebesar 44,49\%., dan berdasarkan perhitungan yang telah dilakukan maka dapat diketahui bahwa kontribusi store atmosphere mempengaruhi keputusan pembelian yaitu sebesar 52,27\%.

\section{Uji Hipotesis}

Uji Hipotesis (Pengaruh Brand Image Terhadap Keputusan Pembelian)

Maka diperoleh $t_{\text {hitung }}$ sebesar 3,688 dan $t_{\text {tabel }}$ sebesar 1,984 dengan taraf signifikan sebesar 0,000. Karena nilai $\mathrm{t}_{\text {hitung }} 3,688>\mathrm{t}_{\text {tabel }} 1,984$ dan nilai signifikannya $0,000<0,05$, maka Ho ditolak, sehingga menyatakan bahwa terdapat pengaruh secara signifikan brand image terhadap keputusan pembelian dapat dibuktikan kebenarannya.

Uji Hipotesis (Pengaruh Store Atmosphere Terhadap Keputusan Pembelian)

Maka diperoleh $t_{\text {hitung }}$ sebesar 3,997 dan $t_{\text {tabel }}$ sebesar 1,984 dengan taraf signifikan sebesar 0,000. Karena nilai $\mathrm{t}_{\text {hitung }} 3,997>\mathrm{t}_{\text {tabel }} 1,984$ dan nilai signifikannya $0,000<0,05$, maka Ho ditolak, sehingga menyatakan bahwa terdapat pengaruh secara signifikan store atmosphere terhadap keputusan pembelian dapat dibuktikan kebenarannya.

Pengaruh Brand image Terhadap Keputusan Pembelian di BUMDes Mart Banjaran 154Majalengka

.000 Berdasarkan hasil perhitungan variabel brand image terhadap keputusan pembelian dengan menggunakan od bantuan program SPSS 16, menyatakan bahwa variabel brand image berpengaruh positif terhadap keputusan pembelian. Artinya semakin tinggi brand image yang melekat pada produk, maka semakin tinggi keputusan pembelian. Hal ini dibuktikan dengan nilai koefisien determinasi yang menunjukan besarnya pengaruh brand image terhadap keputusan pembelian sebesar 44,49\%. Berdasarkan hasil uji t variabel brand image memiliki nilai nilai $t_{\text {hitung }} 3,688$ $<\mathrm{t}_{\text {tabel }} 1,984$ dan nilai signifikannya $0,000>0,05$, maka Ho ditolak, sehingga hipotesis kedua yang menyatakan bahwa terdapat pengaruh secara signifikan brand image terhadap keputusan pembelian dapat dibuktikan kebenarannya. Karena brand image merupakan salah satu unsur penting yang dapat mendorong konsumen untuk membeli produk. Maka brand image merupakan faktor pendorong

\section{Pengaruh Store atmosphere Terhadap Keputusan Pembelian di BUMDes Mart Banjaran Majalengka}

Berdasarkan hasil perhitungan variabel store atmosphere terhadap keputusan pembelian dengan menggunakan bantuan program SPSS 16, menyatakan bahwa variabel store atmosphere berpengaruh positif terhadap keputusan pembelian. Artinya semakin baik store atmosphere dari sebuah toko, maka semakin tinggi keputusan pembelian. Hal ini dibuktikan dengan nilai koefisien determinasi yang menunjukan besarnya pengaruh store atmosphere terhadap keputusan pembelian sebesar $52,27 \%$. Berdasarkan hasil uji $\mathrm{t}$ variabel store atmosphere memiliki nilai $\mathrm{t}_{\text {hitung }} 3,997>\mathrm{t}_{\text {tabel }} 1,984$ dan nilai signifikannya $0,000<0,05$, maka Ho ditolak, sehingga hipotesis ketiga yang menyatakan bahwa terdapat pengaruh secara signifikan store atmosphere terhadap keputusan pembelian dapat dibuktikan kebenarannya. Karena store atmosphere merupakan salah satu cara konsumen mempertimbangkan ketika membeli di toko karena ketika berbelanja juga membutuhkan suasana yang nyaman untuk melakukan pembelian. Maka store atmosphere merupakan faktor pendorong terjadinya keputusan pembelian. 


\section{SIMPULAN DAN SARAN}

\section{Simpulan}

Berdasarkan hasil penelitian dan analisis data yang telah dilakukan di BUMDes Mart Banjaran Majalengka mengenai brand image dan store atmosphere terhadap keputusan pembelian pada BUMDes Mart, maka penulis mengambil kesimpulan sebagai berikut :

1. Brand image berpengaruh secara positif dan signifikan terhadap keputusan pembelian. Artinya, semakin tinggi brand image yang melekat pada produk, maka semakin tinggi keputusan pembelian.

2. Store atmosphere berpengaruh positif dan signifikan terhadap keputusan pembelian. Artinya, semakin baik store atmosphere dari sebuah toko, maka semakin tinggi keputusan pembelian.

\section{Saran}

Berdasarkan hasil penelitian dan pembahasan yang telah dilakukan, maka penulis memberikan saran yang diharapkan dapat memberikan manfaat dan dijadikan bahan pertimbangan bagi pihak-pihak yang berkepentingan, sebagai berikut :

1. Untuk meningkatkan penjualan pihak BUMDes Mart diharapkan agar memilih produk yang akan dijual, misalnya dengan melihat Produk yang lebih banyak dibutuhkan oleh konsumen sehingga omset usaha lebih cepat

2. Diperlukan pemasangan tanda petunjuk produk di BUMDes Mart untuk mempermudah konsumen untuk mencari barang yang mereka inginkan.

3.,Untuk menstimulasi konsumen dalam melakukan pembelian, pihak BUMDes Mart diharapkan untuk memberikan harga yang relatif lebih murah dibandingkan dengan toko lain, misalnya dengan membeli produk dengan harga pokok pembelian yang lebih murah dan meberikan stimulus dalam bentuk point pembelian.

\section{DAFTAR PUSTAKA}

Charles Lamb, W. et. al. 2001. Pemasaran. Edisi Pertama. Jakarta: Salemba Empat.

Christina Widya Utami. 2010. Manajemen Ritel. Edisi 2. Jakarta: Salemba Empat.

Deliyanti Oentoro. 2012. Manajemen Pemasaran Modern. Yogyakarta: Lakbang PRESSindo.

DL Jumono. 2013. Badan Usaha Milik Desa (BUMDes) http://digilib.unila.ac.id
Durianto, D, Sugiarto, \& Sitinjak, T. 2004. Strategi Menaklukan Pasar Melalui Riset Ekuitas dan Perilaku Merek. Jakarta: PT. Gramedia Pustaka Utama.

Engel, James F., Roger D. Blackwell dan Paul W. Miniard. 2001. Perilaku Konsumen. Terjemahan Budjianto. Edisi Kedelapan, Jilid I. Jakarta: Binarupa Aksara.

Fandy Tjiptono. 2005. Pemasaran Jasa. Edisi pertama. Yogyakarta: Bayumedia Publishing.

Fosterr Bob. 2008. Manajemen Ritel. Bandung: Alfabeta.

Freddy Rangkuti. 2006. Teknik Mengukur dan Strategi Meningkatkan Kepuasan Pelanggan. Jakarta: PT. Gramedia Pustaka Utama.

Husein Umar. 2005. Metode Penelitian. Jakarta: Salemba Empat.

Imam Ghozali. 2013. Aplikasi Analisis Multivariate dengan Program SPSS. Semarang: Badan Penerbit Universitas Diponegoro.

Iqbal Hasan. 2009. Analisis Data Penelitian Statistik. Jakarta: Bumi Aksara.

Kotler, Philip. 2010. Manajemen Pemasaran. Alih Bahasa Maya Puspita Karimah. Jakarta: Erlangga.

Kotler, Philip \& Garry Amstrong. 2004. Dasar-dasar Pemasaran. Edisi Kesembilan Jilid 1, dibahasakan oleh Alexander Sindoro. Jakarta: Indeks.

Kotler, Philip \& Garry Amstrong. 2012. Prinsipprinsip Pemasaran. Edisi 13. Jilid 1. Jakarta: Erlangga.

Lupiyoadi, Hamdani. 2006. Manajemen Pemasaran Jasa. Edisi kedua. Jakarta: Salemba Empat.

Samuel, Hatane. 2007. Perilaku dan Keputusan Pembelian Konsumen Restoran Melalui Stimulus 50\% Discount Di Surabaya. Universitas Kristen Petra Surabaya.

Setiadi, J. Nugroho. 2003. Perilaku Konsumen dan Implikasi untuk Strategi dan Penelitian Pemasaran. Jakarta: Prenada Media.

Sugiyono. 2015. Statistika Untuk Penelitian. Bandung: Alfabeta.

Surachman. 2008. Dasar-dasar Manajemen Merek (Alat Pemasaran Untuk Memenangkan Persaingan). Malang: Bayumedia Publishing. 